DOI: 10.31866/2616-7581.3.2.2020.219166

UDC 781.43:81'342.2]:[780.8:780.616.43

\title{
MASTERY OF ARTICULATION IN THE PIANO PERFORMANCE
}

\author{
Nargiz Kengerli-Najafova
}

PhD candidate; Lecturer, Piano Department, Special Pedagogical Training Department;

ORCID: 0000-0003-0525-3237; e-mail: nargiz_kengerli@mail.ru

Baku Music Academy named after Uzeyir Hajibeyli, Baku, Azerbaijan

\section{Abstract}

Based on the scientific research devoted to the problem of articulation in the piano performing art, the article summarizes its main provisions. The author identifies two interrelated aspects of achieving performance articulation. The different functionality of these aspects allows us to present musical articulation in two types: as an author's (or editor's) one and as a performer's one. The author's articulation is the primary basis, objective and unchangeable reality, the idea encoded in the musical text by the composer, and the performer's articulation is a derivative, subjective art infinitely cognoscible and recreated by the performer.

The purpose of the article is to study the problem of articulation in the performing activities of the modern pianists of Azerbaijan.

Research Methodology. The articulation research process has been carried out through methods of analysis, synthesis, and generalization based on listening to performers' recordings of piano works of various styles and forms.

The scientific novelty is that for the first time, the concept of articulation is formulated as an objective reality of a musical text and as a subjective recreation in the music interpretation process, that is, as an author's, editor's and performer's one according to the historical and scientifictheoretical analysis of this problem.

For the first time, the analogy is drawn between the speech punctuation marks against the musical punctuation signs making by a pianist during a performance. The punctuation signs such as musical ones: dot, ellipsis, comma, exclamation and question are introduced.

Conclusions. The leading role of the author's (editor's) and performer's articulation in the music interpretation process, as well as the musical punctuation tools, which significantly influence and determine the mastership in achieving the dramatic integrity of the work, are specified.

The special creative role of the musician in creating a performing articulation based on a deep knowledge of the author's or editor's articulation given in the musical text (legato, legatissimo, non-legato, staccato, marcato, tenuto, accent) is emphasized.

It has been proved that the performing articulation mastership is directly and consistently dependent on the study and analysis of the musical text, the deeper and wider the knowledge of the performer, the more options for creative readings and interpretations are created by the performer.

Keywords: Performing articulation; piano performing art; A. Skryabin "Preludes"; a notable Azerbaijani pianist; Farhad Badalbeyli 


\section{Introduction}

One of the most important problems in the history of the development of musical and performing arts and pedagogy is the problem of articulation - a Latin word "ariticulo" - "to dissect, to pronounce distinctively". Articulation or musical pronunciation is one of the most important elements of the musical performance process since its clarity, expressiveness and content are largely due to the art of articulation.

The study of a wide range of research and methodological experience on the problem of articulation shows that it is one of the most intensely developing areas of musical performance theory. This problem is of scientific interest not only for theoretical musicians but also for performers of various musical specialties, the specificity of which, respectively, determines the performing articulation features.

Among them, piano-performing art has a special place, as it presents, on the one hand, unique timbre-dynamic and technical capabilities, and on the other, certain difficulties in achieving artistic and figurative expressiveness of performance, intonation purity and clarity. The grand piano, as one of the most intelligent musical instruments with the richest resources, requires the formation of special performing skills related to the ability to intonate on it, to achieve the necessary melodious sound production. Such performance excellence was distinguished in the performance by many outstanding musicians of past times, who laid down artistic and aesthetic criteria in pianism related to the singing art on the piano, overcoming the hammer-percussion specifics of the grand piano. These traditions established historically are also peculiar to the best representatives of modern piano art, who are able to "enliven" the piano, to enrich the polyphonic sound intonation expressiveness and melodiousness. The basis for achieving this skill is the pianist's performing articulation art.

B. V. Asafyev (1971) in his book "Musical form as a process" defines music as "the art of intonated meaning", "intonation as a manifestation of thought" (p. 376). Such a scientific position determines the significance of Asafyev's (1971) entire intonation theory, based on which it becomes quite obvious that the music performing process is just the intonation reproducing the process, that is, its ideas, thoughts, and content. And according to this position, the leading role of articulation and the skill of its application in the musical and performing arts becomes quite obvious.

In general, piano articulation is a method of expressive sound production on the piano, which is associated with the ability to correctly implement musical phrasing, with the art to "pronounce" expressively a musical text on the piano, with the skill to resonate the piano sound, to carry out the correct nuance and purity of intonation. All these qualities are essential for achieving performance expressiveness on the piano since without them the performance process becomes incomprehensible and meaningless. These provisions determine the relevance of the research topic.

A fundamental role in the study of articulation problems played B. V. Asafyev's works, especially, his theory of musical intonation, B. Y. Yavorsky's works dedicated to the development of the music-performing arts theory, and M. G.Aranovsky's research regarding the structure and properties of the musical text. I. A. Braudo's major work named "Articulation" (1973) is primarily devoted to the study of the problem of 
articulation. Currently, there are several special studies devoted to the problem of articulation: "Articulation and style in the piano performance" by L. B. Bulatova (1989), "Theoretical foundations of musical articulation" by E. S. Titov (2002) and "Development of articulation skills of an instrumentalist in the process of performing training" by F. H. Valeyeva (2007), "Pronunciation, articulation, stroke-metamorphoses of concepts in science and musical practice" by N. A. Kislitsin (2009), "Musical pronunciation and articulation as the composer's expressive means" by O. A. Bezborodko (2012).

\section{Purpose of the Article and Research Methodology}

The content of this article is of a resumptive nature, as it is the result of major scientific research, the purpose of which was to study the problem of articulation in the performance of modern Azerbaijani pianists.

In order to clearly present the technology of achieving performing articulation in their pianistic art, the interpretation of works of different styles and forms has been studied based on listening to recordings, using methods of analysis, synthesis, and generalization.

\section{Main research material}

Studying the process of musical pronunciation in various interpretations, we draw an analogy with punctuation signs existing in literary speech, since the musical and performing process as "the meaningful pronunciation quality" (Asafyev, 1971) is not limited to the author's instructions of articulation techniques. According to I. Braudo's theory of articulation, the means of articulation are only a formula, the application of which is always a high art. The more solutions to this formula, that is, the richer and more diverse the means of articulation, the higher the skill of the performer, the deeper and more meaningful the performing interpretation process. Each author's or editor's articulation in a musical text is varied to an acceptable extent by the performer, since he determines the measure and quality of its changes and embodiments in accordance with his thesaurus and creative potential.

As one of the numerous examples, we present an analysis of the performance articulation of selected preludes by A. Scriabin, op. 11 No. 22 and op. 16 No. 4,5 in the interpretation by $\mathrm{F}$. Badalbeyli, which is a completely individual reading of these unique masterpieces of the piano miniatures.

Prelude No. $22 \mathrm{~g}$-moll, op. 11 performed by F. Badalbeyli is simple, elegantly, thoughtful, melodious and without excessive romantic pathos. The performance duration is exactly 1 minute and 6 seconds at the specified Lento tempo. Despite the slow tempo, the pianist's interpretation is not static and is dominated by the energy of internal movement, his general aspiration to bar 20 . The chosen tempo helps the pianist to create dramatic richness and imagery in such a concise miniature.

The prelude is a period consisting of 20 bars and an extension in the form of the final episode A tempo (bars 21-25). The pianist, taking into account the rubato indicated in the first bar, slightly delays the first part of bar 1 (D note) and in the similar bar 21 , making a small tenuto on them. 


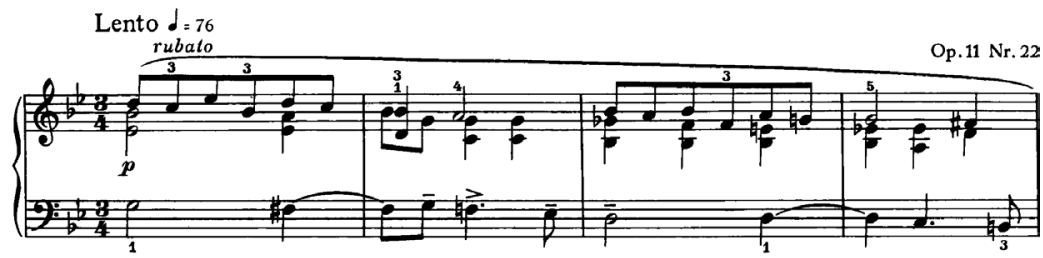

Example 2

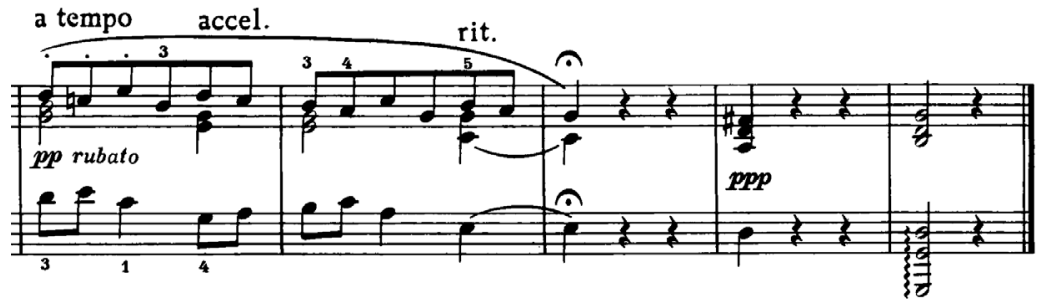

This same method of tempo deviation allows the performer to correctly determine the functionality of the five-bar epilogue, which sounds like a mirror frame at the end of the prelude. It is performed by F. Badalbeyli simply, elegantly, thoughtfully, melodiously and without excessive romantic pathos.

Using accelerando and crescendo, the pianist performs the climactic development, starting with bar 13. At the same time, it highlights the second moves in the bass sequences more vividly, creating a dynamic pumping and trembling-excited character of musical development. This climactic episode creates a certain contrast between the beginning and end of the prelude, contributing to its dramatic integrity.

Example 3

\section{accel.}

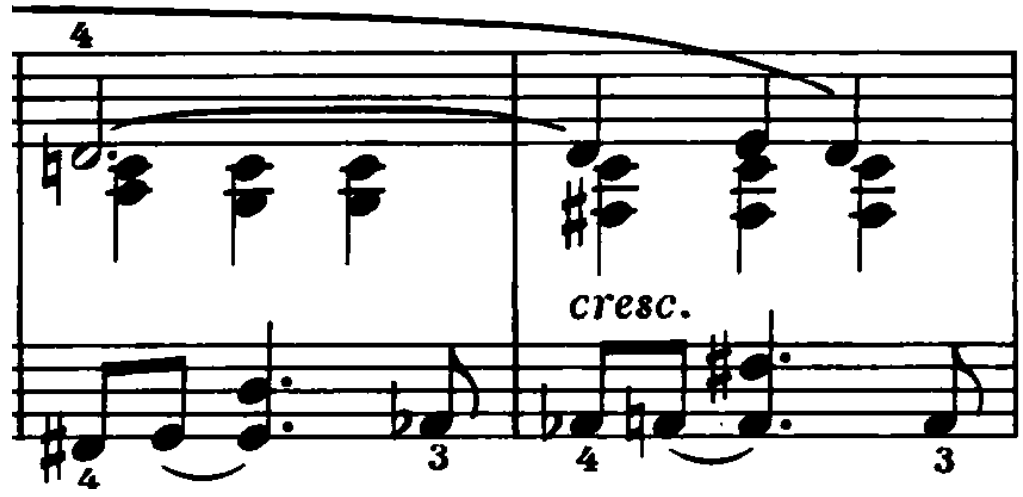

He masterfully uses the dynamic gradation of piano $(p)$ dominating in the prelude, which never sounds the same. The first bar is performed piano ( $p)$, then a small cre- 
scendo (bars 6-7) and a dip in mp (bar 8), then a climactic rise and its ending in two piano ( $p p)$. The epilogue begins with piano (p) (bar 21), then two piano (pp) (bar 23), and then, the chord in the final bar is three piano ( $p p p)$.

The prelude structure is based on imitation polyphony and the pianist skillfully emphasizing its continuity and fluidity creates a single musical development from the first to the twentieth bar, in which he puts the first musical point on the dominant $d$-moll chord. In the musical text, it is repeated twice, but the pianist performs it without repetition, thus emphasizing its important, functional role in the structure of the entire prelude. This chord on the dynamic shade of two piano ( $p p)$ seems to "hang" in the sound space with clear interrogative intonation. The pianist delays it a little further on the fermata, so emphasizing its incompleteness and fret deviation. The pianist puts the final affirmative point in the last bar on the $g$-moll tonic.

The reasonability of the performer's interpretation by F. Badalbeyli is also confirmed by the single glide indicated in the musical text, which unites all musical development during bars 1-14 and the final short imitations in the form of sequential development in the bass.

The performer's articulation of the entire prelude is shown in the table below:

\begin{tabular}{|c|c|c|c|c|}
\hline Bars: & 3 & 22 & 23 & 25 \\
\hline $\begin{array}{c}\text { Musical punctuation } \\
\text { signs }\end{array}$ & - & $?$ & - &. \\
\hline
\end{tabular}

Thus, using the articulation, F. Badalbeyli emphasizes the expressiveness and continuity of the polyphonic texture of the prelude, the richness of its dynamic gradations, and the characteristic fragility and flexibility of the Scriabin's melody. He creates a single musical thought consisting of two tenuto and two endings: an interrogative in bar 20 and an affirmative in the final bar.

Prelude No. 4 es-moll, op. 16, is performed in the Lento tempo. The time of the prelude performance by $\mathrm{F}$. Badalbeyli is 1 minute 10 seconds. The pianist, in general, keeping a slow tempo, creates a literally "live" musical and poetic miniature consisting of four deeply expressive lines. The twelve-bar form of the prelude consists of four motives (three bars in each one), ending with three-chord repetitions. At the end of all the motives, they sound like a kind of ostinato rhythm formula. They all end piano $(p)$, but the pianist performs them differently: the first chord sequence is piano $(p)$, the second is $m f$, the third again is two pianos ( $p p)$, and the fourth is three pianos (ppp).

The first motive (the first thought) is performed on the piano ( $p)$ and with a characteristic vocal intonation - sotto voce. The pianist slightly highlights the first and only quarter note in the first two bars of the motive. Then, to compensate for this delay, he makes a small crescendo against the background of three chord repetitions in the third bar and at the moment when the accruement should reach its natural end, he suddenly removes the sound and starts the second motive on the piano ( $p$ ) (bars 4-6). Also, barely noticeable tenuto is heard for the first fractions of bars (half notes) and ritenuto for the last triol in the fifth bar.

The end of the second motive also has a small crescendo, but it, unlike the first, ends with an even greater increase in sonority, which merges into the third motive and 
reaches a culminating development on $\mathrm{mf}$ in bar 8 . This is followed by a decrease in sonority on diminuendo and the pianist completes the entire musical composition on piano $(p)$ in bar 10. After a complete silence (pause) and seemingly ending, suddenly, like an echo, aftersounds of the first motive are heard. Performed two pianos ( $p p)$ and then three pianos ( $p p p)$, and framing the entire form of the prelude, they sound like an addition to its main musical content.

Example 4
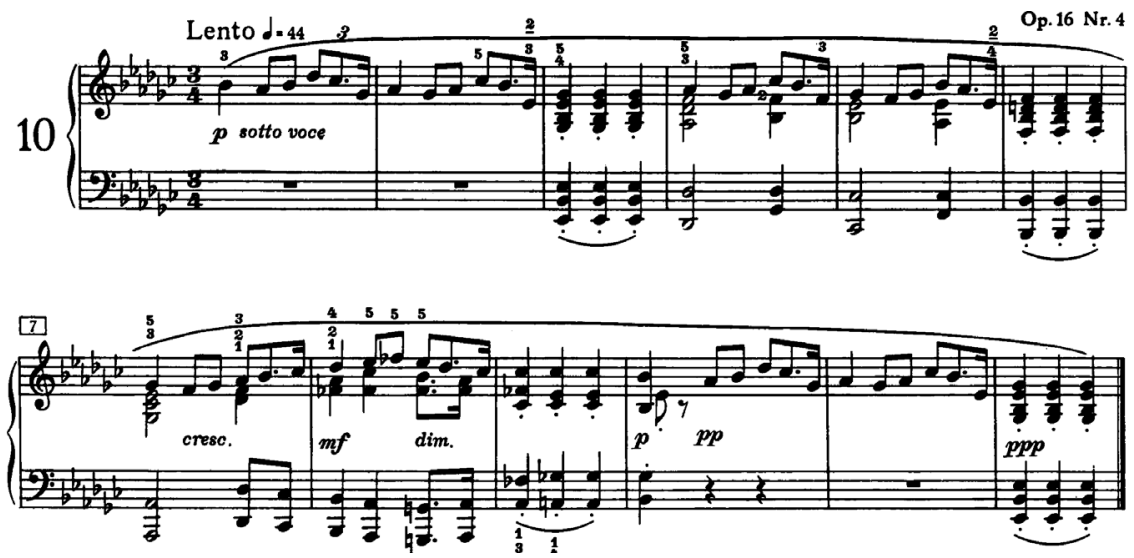

Thus, F. Badalbeyli combines all four motives of the prelude into a single musical narration: the first motive is not completed, but it is connected with the second one, which, in turn, is connected with the third one by using a single crescendo. Here is the only culminating point of the entire narrative and its complete conclusion (bar 10). The fourth and last motive sounds like an echo of a memory core of the musical idea.

It is characteristic that the pianist does not emphasize the motif division, on the basis of which the entire musical form of the prelude is built. It combines the ending of the first one with the second one, second with the third one, highlighting the start of each motive with a barely noticeable tenuto - the longest note, thus creating a complete construction of a single musical thought.

In general, analyzing the performance of the prelude, it should be noted that there are no musical commas and there is a single articulation point in the bar 10 , after which only an echo is heard.

The performer's articulation of the entire prelude is shown in the table below:

Table No. 2

\begin{tabular}{|c|c|c|c|c|}
\hline Bars: & 1 & 4 & 5 & 10 \\
\hline $\begin{array}{c}\text { Musical punctuation } \\
\text { signs }\end{array}$ & - & - & - &. \\
\hline
\end{tabular}

F. Badalbeyli's articulation mastery lies in the fact that the pianist was able to use it to create a single performing drama of this miniature, putting a rich artistic content into its concise form (only 12 bars). The dynamics of its performance clearly recreates the beginning, climax, end, and echo of the entire musical narrative. Just one musical 
thought, as the author's text confirms, in which all 12 bars are connected by a single League (slur). Surprisingly, it is the art of articulation that helps the pianist, recreating in this miniature a deeply philosophical and imaginatively rich artistic content, to make it dramaturgically significant.

Despite the fact that F. Badalbeyli performs it more slowly than V. Sofronitsky, G. Neuhaus and V. Horowitz, he creates a harmonious drama of musical thought in a eeply personal interpretation. A more moderate tempo in his interpretation is quite justified since it helps him to deepen the musical content of the prelude, make its artistic idea more prominent and meaningful.

The prelude, op. 16 No. 5 Fis-dur, is performed in Allegretto tempo, while the composer indicates a possible deviation from the main tempo - rubato. The pianist applies it artistically. Within each sentence, he picks up a little first, and then slows down a little, without breaking the overall unity of the tempo. At the same time, his rubato corresponds to dynamic increases in crescendo and decreases in diminuendo sonority, which also makes this rubato logical. The pianist uses rubato especially clearly in the approach to the two climaxes (bars 11 and 19), and despite the fact that the composer indicates the same forte $(f)$ in both climaxes, the pianist plays the second climax less vividly and, consequently, weakens the tempo deviation. This sounds logically competent and reasonable, both from the point of view of the proximity of the completion of the entire form and recreating the contrast of the climactic increases, which gives the entire performance even more dramatic integrity. The musical form of a prelude is a complex period consisting of four musical sentences: the first is bars 1-4; the second sentence is bars 5-8; the third is bars $9-16$, and the fourth is bars 17-24.

In the musical text, they are clearly underlined by the endings of the glides. It would seem that given the form of the prelude and the words indicated in the text, the pianist would have to make four corresponding musical punctuation signs - dots in bars 4, 8, 16 and 24. But listening to the interpretation of F. Badalbeyli proves once again the rich use of articulation methods. The pianist puts a musical point only at the end of the prelude, namely in bar 24. At the end of the first sentence, the pianist pauses for just a fraction of the second one and then continues moving on to the second sentence. It is a repetition of the first one, but the pianist manages to perform it in a different way.

The contrast is embodied so organically that the feeling of repetition does not arise, it sounds more major and brighter than the first one and, thus, creates a dynamic logical connection between the first and third sentences, which sounds even more intense, since it contains the main climax of the entire prelude. Then, in the fourth sentence, the dynamics subsides, despite another minor climax in the pianist's mind, and reaches the full completion.

The performer's articulation of the prelude is shown in the table below:

Table No.3

\begin{tabular}{|c|c|c|c|c|c|}
\hline Bars: & 1 & 5 & 9 & 17 & 24 \\
\hline $\begin{array}{c}\text { Musical punctuation } \\
\text { signs }\end{array}$ & - & - & - & - &. \\
\hline
\end{tabular}


It is important to note one more feature of performance. Indicated in the musical text in bars 1,5,13, 21 tenuto marks on the three notes, are performed by the pianist almost imperceptibly. He only gives them a greater melodic expressiveness. F. Badalbeyli considers these tenuto marks logically quite correctly, since if you emphasize literally every sound (as indicated in the musical text), it will only create a fragmentation of the melodic thought, violating its integrity and flight, which is very characteristic for the style of Scriabin's music.

Thus, in the prelude, instead of four musical points, the pianist makes one affirmative-final point, while only emphasizing the tenuto beginning of each sentence. Such a construction is certainly due to his dramatic mastership, which helps to create an amazing flight of performance, almost the "air" movement of virtually continuous musical development.

It is interesting that the pianist's performance creates a sense of musical "openwork", flexibility, melodic movement ornateness, it literally breathes with "frosty patterns on the glass". He skillfully uses author's dynamic instructions, Despite the fact that in the first, second and fourth sentences the same nuance - two pianos (pp) (bars 3,7 and 23) is indicated the pianist actually plays them all differently: the first sounds quiet, the second is slightly brighter and only the third, the last, fully corresponds to one specified in the text two piano (pp). This contrasting use of dynamics on two pianos also contributes to the dramatic integrity of the performance and allows the pianist to combine the musical development of the prelude with dynamic richness.

Performing articulation of A. Scriabin's preludes in the pianist's interpretation is aimed, on the one hand, at achieving intonation clarity and expressiveness, and, on the other hand, at creating dramatic integrity and harmony. In such a way, he "cements" the performance form, not allowing it to break up into motives and sentences, creates a series of contrasting, vividly shaped miniatures.

All three preludes, different in form and musical content, are interpreted by F. Badalbeyli as a kind of concise musical narration. In all three preludes, the pianist puts one musical point, thus emphasizing the unity of musical thought.

Analysis of the three preludes by A. Scriabin shows that F. Badalbeyli in his interpretation recreates his famous phrase: "Music is alive with a thought". The pianist masterfully embodies, in the words of V. Delson (1966), “... a bold thought and an inspired emotion in a living unity" (p. 64).

The pianist's performing articulation confirms that even in the interpretation of the music of romantic composers, uncontrolled emotions, unrestrained feelings and the unreasonableness of their expression are alien to him. With the help of articulation, he creates harmonious musical and artistic canvases full of vital content and a clear balance of human thoughts and feelings.

Thus, summarizing the process of performing articulation on the example of three preludes by A. Scriabin and other works interpreted by F. Badalbeyli, we note that the skill of articulation is determined not only by the sign indicated in the musical text but also by the meaning which the pianist puts in this sign. After all, each stroke, such as staccato, tenuto, etc., as well as punctuation signs, such as dot, comma, exclamation, question, ellipsis, and etc., can be pronounced with different degrees of expressiveness. The ability of a music performer to find, logically justify 
and embody this degree of expression in his art is an indicator of the highest skill of performing articulation.

The highest and unique skill of performing articulation in the piano art of F. S. Badalbeyli is manifested in the exceptional meaningfulness of the performed, clarity of musical pronunciation, logical validity of the musical narrative, which ultimately determines the depth and content of its interpretations, their dramatic integrity. Each articulation sign (legato, legatissimo, non-legato, staccato, marcato, tenuto, accent) of a musical text is deeply comprehended by the pianist and reveals its functionality in relation to the nearest and future musical development, he (as if from a height) plans in advance, anticipates the entire prospect of performing recreation. In accordance with this, the pianist distributes musical and syntactic punctuation signs (dots, commas, exclamation, question, ellipsis, and etc.), creating true examples of musical expressiveness and clarity, which is an indicator of his highest skill in achieving performance articulation.

\section{Conclusions}

So, based on numerous studies regarding the concept of musical articulation and the analysis of various interpretations, in this scientific terminology, we differentiate two aspects that, despite their mutual influence and interdependence, are two different content components: the first source component represents musical articulation as an objective reality specified by the composer in the musical text, the second derivative component is its subjective recreation by the performer in the process of interpreting the work. Both aspects play a crucial role in creating a clear intonation expressiveness of musical speech and dramaturgic integrity of the work performed. The different functionality of these aspects allows us to present musical articulation in two forms: as the author's (or editor's) one and as the performer's one.

In general, performing articulation, based on the notation in the musical text, represents the development of musical speech with its characteristic signs of musical-syntactic punctuation, which contribute to the expressiveness, logical validity and dramaturgic integrity of its content. In other words, the clarity and richness of content in the musical narrative depend on the skill of the performing articulation, on how the performer implements a unified (single) process of musical forms generation with characteristic tendencies of internal syntactic development. Musical speech (sound, motive, phrase, episode) can be made not only with different intonations (affirmative, interrogative, exclamatory, etc.), but also with their numerous shades. Everything is determined by the performer's attitude to it, by the level of his/her overall spiritual and professional development.

If the author's or editor's articulation has a special indication recorded by the composer in the musical text, the performing articulation represents the creative process of its subjective recreation, since each artist intonates it in accordance with his/ her thesaurus, intellectual, emotional, spiritual and technical potential. It is thanks to the mastery of performing articulation, the musical text "comes to life", becomes meaningful, is filled with the significance of the content and becomes an exciting musical narrative for the listener. 
The author's articulation is the primary principle, an objective and unchanging reality, thought coded by the composer, and performing articulation is a derivative, subjective, infinitely cognizable art, creatively recreated by the performer. The higher the level of the musician's intellectual, artistic, emotional, and spiritual and personal development, the further he/she moves away from the mechanical decoding of the author's text, the deeper he cognizes it, the higher the skill and richness of his performing interpretations.

In general, the analysis of performing articulation on the example of selected works in the interpretation of prominent representative of the modern Azerbaijani pianistic school allows us to summarize the following statement: pianist precisely observes the author's (editor's) articulation, especially in works of the musical classicism era, while in interpreting works of the romanticism era and modern music, they, relying on the articulation indicated in the musical text, creatively refract it in accordance with their own potential and set artistic and aesthetic purposes.

One of the main characteristic features of their performing articulation is the mastery of intoning on the piano, the ability to clearly express a musical thought and to logically build the entire musical narrative. Exactly observing the articulation touches indicated in the musical text, the pianist reinterprets them in full accordance with the logic of musical development, and articulate clearly, achieving purity of intonation and performing expressiveness.

The mastery of their performing articulation is the most important foundation on which their general performing culture has formed. It represents a valuable methodological experience for the next generation of teachers and pianists. The followings are the basic principles of the pianist's performing articulation:

- the pianist detail and study the musical text as much as possible;

- the pianist thinks over the whole performing concept to the smallest nuances;

- pianist allows insignificant digressions that are logically justified from the artistic expression point of view;

- performing articulation in classical works is a particular difficulty since maximal intonation purity and clarity is an important aesthetic criterion for pianist's performance;

- enriching the basic techniques of articulation, pianist uses them with a variety of intonations to achieve the artistic-figurative richness of content;

- the pianist recreates the work's dramaturgic integrity using the signs of musical syntactic pronunciation (dots, commas, ellipsis, question and exclamation marks, tenuto, accent);

- while interpreting various works, pianists exhibit varying degrees of achievement in performing articulation, that is due to their musical talent and professionalism;

- talented pianist-educators, who succeeded in implementing continuity of generations and convey the historically established traditions of expressive intonation on the piano, played a significant role in the formation of their performing articulation.

Thus, the results of this study confirmed that performing articulation, being one of the most important areas in the theory of pianism and representing an objective reality, necessitates its creative understanding and subjective recreation. However, it should be noted that the right to this creativity must first be earned by the endless work of 
the mind, heart and hands. Mastery of performing articulation requires the intensive development of psychological (intellectual, emotional, spiritual) and purely pianistic abilities, the interaction of which contributes to its full and successful implementation.

\section{References}

Asafyev, B. (1971). Muzykal'naya forma kak protsess [Musical Form as a Process] (Book 1-2). Muzyka [in Russian].

Braudo, I. (1973). Artikulyatsiya: (O proiznoshenii melodii) [Articulation: (About the Pronunciation of the Melody)] (2nd ed.). Muzyka [in Russian].

Bulatova, L. B. (1991). Stilevye cherty artikulyatsii v fortepiannoi muzyke XVIII - pervoi poloviny XIX veka [Style Features of Articulation in Piano Music of the 18th - First Half of the 20th Centuries]. Muzyka [in Russian].

Delson, V. Yu. (1966). Genrikh Neigauz [Heinrich Neuhaus]. Muzyka [in Russian].

Golubovskaya, N. I. (2004). Ob artikulyatsii fortepiannykh proizvedenii Motsarta [About Articulation of Mozart's Piano Works]. In A. M. Merkulov (Comp.), Kak ispolnyat' Motsarta [How to Perform Mozart] (pp. 57-66). Klassika-XXI [in Russian].

Khentova, S. M. (1961). Margarita Long [Marguerite Long]. Muzgiz [in Russian].

Kislitcyn, N. A. (2009). Proiznoshenie, artikulyattsiya, shtrikh - metamorfozy ponyatii v nauke i muzykal'noi praktike [Pronunciation, Articulation, Stroke - Metamorphosis of Concepts in Science and Musical Practice]. Vestnik Chelyabinskogo Gosudarstvennogo Universiteta. Seriya: Filologiya. Iskusstvovedenie, 37, 182-186 [in Russian].

Sokol, A. V. (1996). Teoriya muzykal'noi artikulyatsii [Musical Articulation Theory]. OKFA [in Russian].

Sokol, A. V. (2007). Ispolnitel'skie remarki, obraz mira i muzykal'nyi stil' [Performing Directions, Image of the World and Musical Style]. Moriak [in Russian].

Titov, Y. S. (2002). Teoreticheskie osnovy muzykal'noi artikulyatsii [Theoretical Foundations of Musical Articulation] (Abstract of PhD Dissertation). Rostov State Rachmaninov Conservatory, Rostov-on-Don [in Russian].

Valeyeva, F. H. (2007). Razvitie artikulyatsiionnogo masterstva muzykanta-instrumentalista $\checkmark$ protsesse ispolnitel'skoi podgotovki na etape vysshego professional'nogo obrazovaniya [The Development of the Articulatory Skills of an Instrumental Musician in the Process of Performing Training at the Stage of Higher Professional Education] (Abstract of PhD Dissertation). Ural State Pedagogical University, Yekaterinburg [in Russian]. 


\section{МАЙСТЕРНІСТЬ ВИКОНАВСЬКОÏ АРТИКУЛЯЦІЇ НА РОЯЛІ}

\section{Наргіз Кенгерлі-Наджафова}

докторант, викладач кафедри фортепіано, викладач кафедри спеціальної педагогічної підготовки; ORCID: 0000-0003-0525-3237; e-mail: nargiz_kengerli@mail.ru

Бакинська музична академія імені Узеіра Гаджибейлі, Баку, Азербайджан

\section{Анотація}

На основі проведеного наукового дослідження, присвяченого проблемі артикуляції в фортепіанно-виконавському мистецтві, узагальнено ії основні положення. Автор виявляє два взаємопов'язаних аспекти в досягненні виконавської артикуляції. Різна функціональність цих аспектів дозволяє представити музичну артикуляцію у двох видах: як авторську (або редакторську) і як виконавську. Авторська артикуляція це першооснова, об'єктивна і незмінна даність, закодована в нотному тексті думка, а виконавська артикуляція - це похідне, суб'єктивне, нескінченно пізнаване і відтворюване виконавцем мистецтво.

Мета дослідження - вивчення проблеми артикуляції у виконавській діяльності сучасних азербайджанських піаністів.

Методологія дослідження. Процес дослідження артикуляції здійснювався за допомогою методів аналізу, синтезу та узагальнення на основі прослуховування виконавських записів фортепіанних творів, різних за стилем і формою.

Наукова новизна дослідження визначається тим, що вперше на основі історичного та науково-теоретичного аналізу даної проблеми формулюється поняття артикуляції як об'єктивної даності нотного тексту і як суб'єктивного відтворення в процесі інтерпретації музики, тобто як авторської, редакторської і як виконавської. Вперше проводиться аналогія між знаками пунктуації в мові й знаками музичної пунктуації, здійснюваних піаністом в процесі виконання. Вводяться такі розділові знаки, як музичні: крапка, три крапки, кома, вигук, питання.

Висновки. Визначено провідну роль авторської (редакторської) і виконавської артикуляції в процесі інтерпретації музики, а також засобів музичної пунктуації, які значною мірою впливають і обумовлюють майстерність в досягненні драматургічної цілісності твору. Підкреслено особливу творчу роль музиканта-виконавця в створенні виконавської артикуляції, що спирається на глибоке пізнання авторської або редакторської артикуляції, даної в нотному тексті (legato, legatissimo, non legato, staccato, marcato, tenuto, accent). Обґрунтовано висновок про те, що майстерність виконавської артикуляції знаходиться в прямій і послідовній залежності від вивчення та аналізу нотного тексту - чим глибше і ширше пізнання виконавця, тим більше варіантів творчих прочитань-інтерпретацій він створює.

Ключові слова: виконавська артикуляція; фортепіанно-виконавське мистецтво; А. Скрябін «Прелюдії»; азербайджанський піаніст Фархад Бадалбейлі 


\title{
МАСТЕРСТВО ИСПОЛНИТЕЛЬСКОЙ АРТИКУЛЯЦИИ НА РОЯЛЕ
}

\author{
Наргиз Кенгерли-Наджафова
}

докторант, преподаватель кафедры фортепиано, преподаватель кафедры специальной педагогической подготовки; ORCID: 0000-0003-0525-3237; e-mail: nargiz_kengerli@mail.ru Бакинская музыкальная академия имени Узеира Гаджибейли, Баку, Азербайджан

\section{Аннотация}

На основе проведенного научного исследования, посвященного проблеме артикуляции в фортепианно-исполнительском искусстве, обобщено ее основные положения. Автор выявляет два взаимосвязанных аспекта в достижении исполнительской артикуляции. Различная функциональность этих аспектов позволяет представить музыкальную артикуляцию в двух видах: как авторскую (или редакторскую) и как исполнительскую. Авторская артикуляция - это первооснова, объективная и неизменная данность, закодированная композитором в нотном тексте мысль, а исполнительская артикуляция - это производное, субъективное, бесконечно познаваемое и воссоздаваемое исполнителем искусство.

Цель исследования - изучение проблемы артикуляции в исполнительской деятельности современных азербайджанских пианистов.

Методология исследования. Процесс исследования артикуляции осуществлялся с помощью методов анализа, синтеза, и обобщения на основе прослушивания исполнительских записей фортепианных произведений различных по стилю и форме.

Научная новизна исследования определяется тем, что впервые на основе исторического и научно-теоретического анализа данной проблемы формулируется понятие артикуляции как объективной данности нотного текста и как субъективного воссоздания в процессе интерпретации музыки, то есть как авторской, редакторской и как исполнительской. Впервые проводится аналогия между знаками препинания в речи и знаками музыкального препинания, осуществляемые пианистом в процессе исполнения. Вводятся такие знаки препинания, как музыкальные: точка, многоточие, запятая, восклицание, вопрос.

Выводы. Определено ведущую роль авторской (редакторской) и исполнительской артикуляции в процессе интерпретации музыки, а также средств музыкального препинания, которые в значительной степени влияют и обусловливают мастерство в достижении драматургической целостности произведения. Подчеркнуто особую творческую роль музыканта-исполнителя в создании исполнительской артикуляции, опирающейся на глубокое познание авторской или редакторской артикуляции, данной в нотном тексте (legato, legatissimo, non legato, staccato, marcato, tenuto, accent). Обосновано вывод о том, что мастерство исполнительской артикуляции находится в прямой и последовательной зависимости от изучения и анализа нотного текста - чем глубже и шире познания исполнителя, тем больше вариантов творческих прочтенийинтерпретаций он создает.

Ключевые слова: исполнительская артикуляция; фортепианно-исполнительское искусство; А. Скрябин «Прелюдии»; азербайджанский пианист Фархад Бадалбейли 